\title{
USDA
}

\section{United States Housing Brief, August 2017}

\author{
Delton Alderman
}
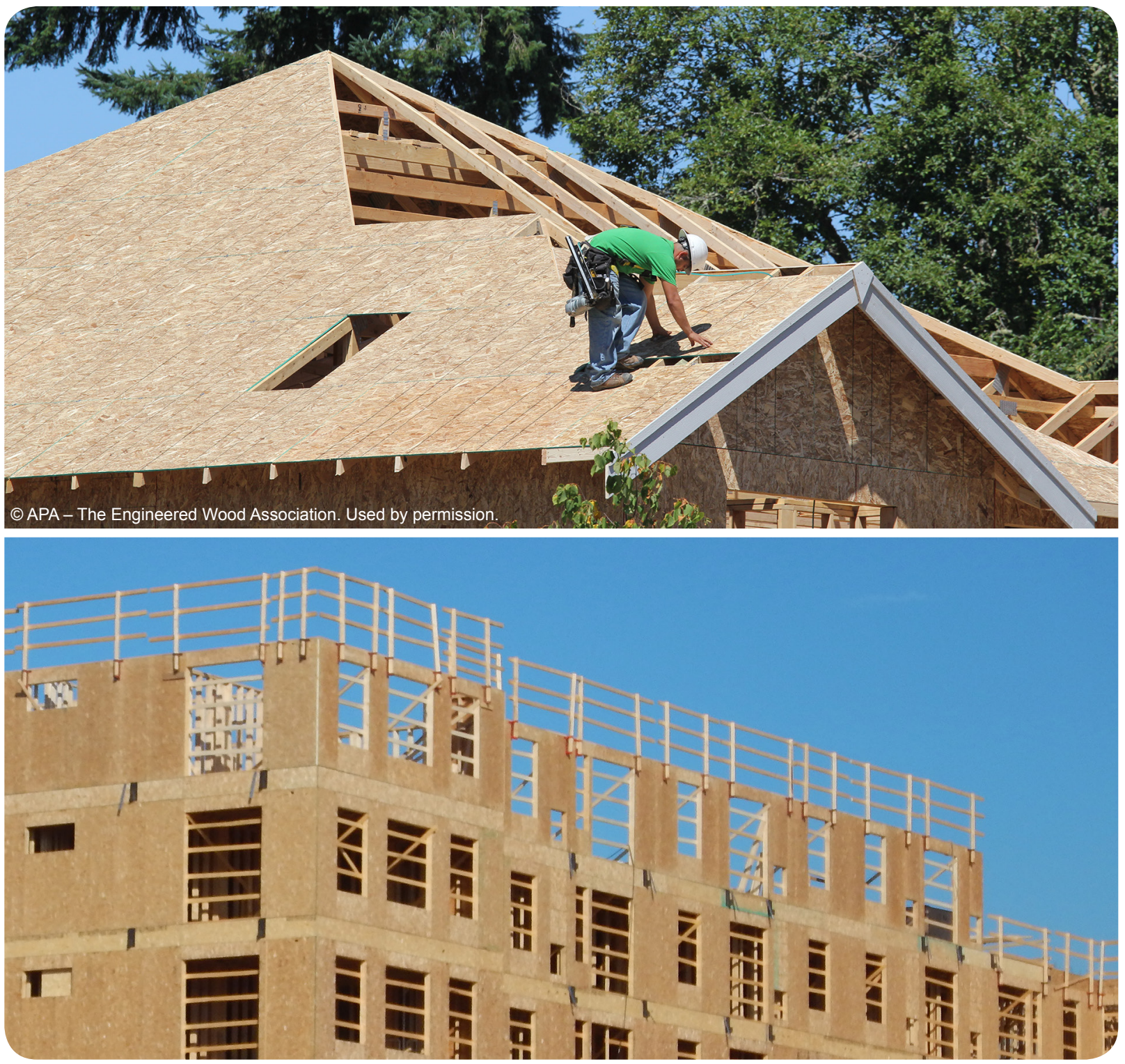


\section{Abstract}

Housing starts and new single-family sales appear to have stalled on a monthly and year-over-year basis. The bright spot in August was single-family starts and aggregate housing permits. Regionally, data were mixed across all sectors. New construction spending's contribution to U.S. gross domestic product decreased on a quarterly basis.

Keywords: housing permits, starts, under construction, completions, construction spending, new sales, existing sales, regional housing data, economic indicators

\section{Contents}

Summary ….............................................................. 1

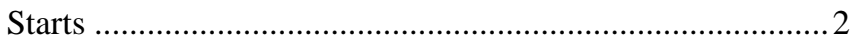

Permits ............................................................................ 2

Housing under Construction.............................................. 3

Housing Completions ...................................................... 3

New Single-Family House Sales ....................................... 4

Private Residential Construction Spending ......................... 4

Existing House Sales ......................................................... 5

Literature Cited ......................................................... 5

Glossary .................................................................... 6

January 2018

Alderman, Delton. 2018. United States Housing Brief, August 2017. Research Note FPL-RN-0353. Madison, WI: U.S. Department of Agriculture, Forest Service, Forest Products Laboratory. 6 p.

A limited number of free copies of this publication are available to the public from the Forest Products Laboratory, One Gifford Pinchot Drive, Madison, WI 53726-2398. This publication is also available online at www.fpl.fs.fed.us. Laboratory publications are sent to hundreds of libraries in the United States and elsewhere.

The Forest Products Laboratory is maintained in cooperation with the University of Wisconsin.

The use of trade or firm names in this publication is for reader information and does not imply endorsement by the United States Department of Agriculture (USDA) of any product or service.

In accordance with Federal civil rights law and U.S. Department of Agriculture (USDA) civil rights regulations and policies, the USDA, its Agencies, offices, and employees, and institutions participating in or administering USDA programs are prohibited from discriminating based on race, color, national origin, religion, sex, gender identity (including gender expression), sexual orientation, disability, age, marital status, family/parental status, income derived from a public assistance program, political beliefs, or reprisal or retaliation for prior civil rights activity, in any program or activity conducted or funded by USDA (not all bases apply to all programs). Remedies and complaint filing deadlines vary by program or incident.

Persons with disabilities who require alternative means of communication for program information (e.g., Braille, large print, audiotape, American Sign Language, etc.) should contact the responsible Agency or USDA's TARGET Center at (202) 720-2600 (voice and TTY) or contact USDA through the Federal Relay Service at (800) 877-8339. Additionally, program information may be made available in languages other than English.

To file a program discrimination complaint, complete the USDA Program Discrimination Complaint Form, AD-3027, found online at http://www.ascr.usda/gov/complaint_filing_cust.html and at any USDA office or write a letter addressed to USDA and provide in the letter all of the information requested in the form. To request a copy of the complaint form, call (866) 632-9992. Submit your completed form or letter to USDA by: (1) mail: U.S. Department of Agriculture, Office of the Assistant Secretary for Civil Rights, 1400 Independence Avenue, SW, Washington, D.C. 20250-9410; (2) fax: (202) 690-7442; or (3) email: program.intake@usda.gov.

USDA is an equal opportunity provider, employer, and lender. 


\section{United States Housing Brief, August 2017}

Delton Alderman, Research Forest Products Technologist

USDA Forest Service, Forest Products Laboratory, Madison, Wisconsin, and

Northern Research Station, Princeton, West Virginia

\section{Summary}

Historically, and currently, new single-family (SF) construction is the largest value-added wood products consuming sector, and is a leading coincident economic indicator of the U.S. economy. The aggregate U.S. housing market encountered a speed bump in August, as many monthly indicators were negative on a month-over-month basis. Housing starts and new SF sales have rolled over-on a monthly and year-over-year basis. However, on a yearover-year basis, the majority were positive. Construction spending was minimally positive; yet robust, on a yearover-year basis.

This housing brief includes housing starts, permits, houses under construction, completions, sales, and construction spending data available from the U.S Department of Commerce and the National Association of Realtors. The data are compared on a month-over-month (M/M) and yearover-year (Y/Y) basis. For more detailed information and commentary, the monthly "The Virginia Tech-U.S. Forest Service Housing Commentary" is available at http://woodproducts.sbio.vt.edu/housing-report. Additionally, in-depth semi-annual and annual housing construction research is available via Treesearch (https://www.fs.usda.gov/treesearch/) by inputting "Alderman".

\begin{tabular}{|c|c|c|}
\hline Category $^{\mathbf{a}}$ & $\begin{array}{l}\text { Month- } \\
\text { over- } \\
\text { month } \\
\text { change }\end{array}$ & $\begin{array}{c}\text { Year- } \\
\text { over-year } \\
\text { change }\end{array}$ \\
\hline $\begin{array}{l}\text { Housing starts } \\
\text { (total) }\end{array}$ & $\nabla 0.8 \%$ & $\begin{array}{l}1.4 \% \\
\end{array}$ \\
\hline Single-family & $\Delta 1.6 \%$ & ه $17.1 \%$ \\
\hline Multi-family & $\nabla 6.5 \%$ & $\nabla 24.7 \%$ \\
\hline $\begin{array}{l}\text { Housing permits } \\
\text { (total) }\end{array}$ & $\Delta \quad 5.7 \%$ & $\Delta \quad 8.3 \%$ \\
\hline Single-family & $\nabla 1.5 \%$ & $\Delta \quad 7.7 \%$ \\
\hline Multi-family & ه 19.6\% & - $9.4 \%$ \\
\hline $\begin{array}{l}\text { Housing under } \\
\text { construction (total) }\end{array}$ & $\Delta 1.3 \%$ & $\Delta \quad 4.6 \%$ \\
\hline Single-family & $\Delta \quad 2.2 \%$ & A $10.5 \%$ \\
\hline Multi-family & $\nabla \quad 0.7 \%$ & $\nabla \quad 0.5 \%$ \\
\hline $\begin{array}{l}\text { Housing } \\
\text { completions (total) }\end{array}$ & $\nabla \quad 10.2 \%$ & $\Delta \quad 3.4 \%$ \\
\hline Single-family & $\nabla \quad 13.3 \%$ & $\nabla \quad 2.7 \%$ \\
\hline Multi-family & $\nabla 3.0 \%$ & - $18.6 \%$ \\
\hline $\begin{array}{l}\text { New single-family } \\
\text { house sales }\end{array}$ & $\nabla 3.4 \%$ & $1.2 \%$ \\
\hline $\begin{array}{l}\text { Private residential } \\
\text { construction } \\
\text { spending }\end{array}$ & $\Delta \quad 0.4 \%$ & $\Delta \quad 11.6 \%$ \\
\hline $\begin{array}{l}\text { Single-family } \\
\text { construction } \\
\text { spending }\end{array}$ & $\Delta \quad 0.3 \%$ & ه 11.1\% \\
\hline $\begin{array}{l}\text { Existing house } \\
\text { sales }^{\mathrm{b}}\end{array}$ & $\nabla \quad 1.7 \%$ & $0.2 \%$ \\
\hline
\end{tabular}




\section{Starts}

Total starts in August 2017 were at a seasonally adjusted annual rate (SAAR) of $1,180,000$. This is $0.8 \%$ less than July 2017 and 1.4\% more than August 2016. Single-family starts were 851,000, which is 1.6\% more than July 2017. Multi-family (MF) starts of two to four units were 6,000 and five units or more were 323,000 (Census Bureau 2017a). August 2017 total starts were less than the 58-year average of $1,439,000$.

Regionally, the South remains the strongest market, where total starts were 563,000, of which 463,000 were SF and 100,000 were MF. The West followed, with total starts of 312,000 , of which 212,000 were SF and 100,000 were MF. Total Midwest starts were 200,000, of which 110,000 were SF and 90,000 were MF. The Northeast recorded total starts of 105,000, of which 66,000 were SF and 39,000 were MF (Census Bureau 2017a). Table 1 provides specific information on each housing start category for August 2017.

Table 1-National and regional U.S. housing starts for August 2017 in comparison to July 2017 and August 2016

\begin{tabular}{lcccc}
\hline & & & $\begin{array}{c}\text { Multi- } \\
\text { family } \\
(2-4\end{array}$ & $\begin{array}{c}\text { Multi- } \\
\text { family } \\
(\geq 5 \\
\text { units })\end{array}$ \\
\hline Aug-17 & $1,180,000$ & 851,000 & 6,000 & 323,000 \\
Jul-17 & $1,190,000$ & 838,000 & 9,000 & 343,000 \\
$\begin{array}{l}\text { Aug-16 } \\
\text { family }\end{array}$ & $1,164,000$ & 727,000 & 17,000 & 420,000 \\
$\begin{array}{l}\text { Month- } \\
\text { over- }\end{array}$ & $-0.8 \%$ & $1.6 \%$ & $-33.3 \%$ & $-5.8 \%$ \\
$\begin{array}{l}\text { month } \\
\text { change }\end{array}$ & & & & \\
$\begin{array}{l}\text { Year- } \\
\text { over- }\end{array}$ & $1.4 \%$ & $17.1 \%$ & $-64.7 \%$ & $-23.1 \%$ \\
$\begin{array}{l}\text { year } \\
\text { change }\end{array}$ & & & & \\
\end{tabular}

\begin{tabular}{lcccc} 
& Northeast & Midwest & \multicolumn{1}{l}{ South } & West \\
\cline { 2 - 5 } Aug-17 & 105,000 & 200,000 & 563,000 & 312,000 \\
Jul-17 & 115,000 & 164,000 & 611,000 & 300,000 \\
Aug-16 & 133,000 & 170,000 & 562,000 & 299,000 \\
Month- & $-8.7 \%$ & $22.0 \%$ & $-7.9 \%$ & $4.0 \%$ \\
over- & & & \\
month \\
change
\end{tabular}

\section{Permits}

Total building permits issued in August 2017 were at a SAAR of 1,300,000. This is 5.7\% more than July 2017 and 8.3\% more than August 2016. SF permits were 800,000, which was $1.5 \%$ less than July 2017. MF permits of two to four units were 36,000 and five units or more were 464,000 (Census Bureau 2017a). Historically, MF permits can be extremely variable, $\mathrm{M} / \mathrm{M}$ and $\mathrm{Y} / \mathrm{Y}$.

Regionally, the South remains the strongest market, where total permits issued were 646,000 , of which 431,000 were SF and 215,000 were MF. The West followed, with total permits of 362,000, of which 199,000 were SF and 163,000 were MF. Midwest total permits were 185,000, of which 112,000 were SF and 73,000 were MF. In the Northeast, total permits were 107,000 , of which 58,000 were SF and 49,000 were MF (Census Bureau 2017a). Table 2 provides specific information on each permit category for August 2017.

Table 2-National and regional U.S. housing permits for August 2017 in comparison to July 2017 and August 2016

\begin{tabular}{lcccc}
\hline & $\begin{array}{c}\text { Total } \\
\text { permits }^{\mathrm{a}}\end{array}$ & $\begin{array}{c}\text { Single- } \\
\text { family }\end{array}$ & $\begin{array}{c}\text { Multi- } \\
\text { family (2- } \\
4 \text { units) }\end{array}$ & $\begin{array}{c}\text { Mumily } \\
\text { family } \\
\text { units })\end{array}$ \\
\hline Aug-17 & $1,300,000$ & 800,000 & 36,000 & 464,000 \\
Jul-17 & $1,230,000$ & 812,000 & 40,000 & 378,000 \\
Aug-16 & $1,200,000$ & 743,000 & 36,000 & 421,000 \\
$\begin{array}{l}\text { Month- } \\
\text { over- }\end{array}$ & $5.7 \%$ & $-1.5 \%$ & $-10.0 \%$ & $22.8 \%$ \\
month & & & & \\
change & & & & \\
$\begin{array}{l}\text { Year- } \\
\text { over- }\end{array}$ & $8.3 \%$ & $7.7 \%$ & $0.0 \%$ & $10.2 \%$ \\
$\begin{array}{l}\text { year } \\
\text { change }\end{array}$ & & & & \\
\end{tabular}

\begin{tabular}{lcccc} 
Aug-17 & 107,000 & 185,000 & 646,000 & 362,000 \\
\cline { 2 - 5 } Jul-17 & 123,000 & 170,000 & 623,000 & 314,000 \\
Aug-16 & 117,000 & 192,000 & 606,000 & 285,000 \\
$\begin{array}{l}\text { Month- } \\
\text { over- }\end{array}$ & $-13.0 \%$ & $8.8 \%$ & $3.7 \%$ & $15.3 \%$ \\
$\begin{array}{l}\text { month } \\
\text { change }\end{array}$ & & & \\
$\begin{array}{l}\text { Year- } \\
\text { over- }\end{array}$ & $-8.5 \%$ & $-3.6 \%$ & $6.6 \%$ & $27.0 \%$ \\
$\begin{array}{l}\text { year } \\
\text { change }\end{array}$ & & & & \\
a Source: U.S. Department of Commerce-Construction (SAAR).
\end{tabular}




\section{Housing under Construction}

Total housing under construction (HUC) issued in August 2017 were at a SAAR of $1,082,000$. This is $1.3 \%$ more than July 2017 and 4.6\% greater than August 2016. SF HUC was 472,000 , which is $2.2 \%$ more than July 2017 . MF HUC of two to four units were 9,000 and five units or more were 601,000 (Census Bureau 2017a).

Regionally, the South remains the strongest market, where the total HUC was 448,000 , of which 228,000 were SF and 220,000 were MF. The West followed with a total HUC of 294,000 units, of which 117,000 were SF and 177,000 were MF. The Northeast total HUC was 187,000, of which 50,000 were SF and 137,000 were MF. Midwest total HUC was 153,000 , of which 77,000 were SF and 76,000 were MF (Census Bureau 2017a). Table 3 provides specific information for each housing under construction category for August 2017.

Table 3-National and regional U.S. housing under construction for August 2017 in comparison to July 2017 and August 2016

\begin{tabular}{|c|c|c|c|c|}
\hline & $\begin{array}{l}\text { Total under } \\
\text { construction }^{\mathrm{a}}\end{array}$ & $\begin{array}{l}\text { Single- } \\
\text { family }\end{array}$ & 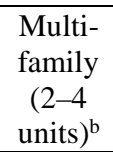 & $\begin{array}{l}\text { Multi- } \\
\text { family } \\
\text { ( } \geq 5 \\
\text { units) }\end{array}$ \\
\hline Aug-17 & $1,082,000$ & 472,000 & 9,000 & 601,000 \\
\hline Jul-17 & $1,068,000$ & 462,000 & 9,000 & 597,000 \\
\hline Aug-16 & $1,034,000$ & 427,000 & 11,000 & 596,000 \\
\hline $\begin{array}{l}\text { Month- } \\
\text { over- } \\
\text { month } \\
\text { change }\end{array}$ & $1.3 \%$ & $2.2 \%$ & $0.0 \%$ & $0.7 \%$ \\
\hline $\begin{array}{l}\text { Year- } \\
\text { over- } \\
\text { year } \\
\text { change }\end{array}$ & $4.6 \%$ & $10.5 \%$ & $-18.2 \%$ & $0.8 \%$ \\
\hline
\end{tabular}

\begin{tabular}{|c|c|c|c|c|}
\hline & Northeast & Midwest & South & West \\
\hline Aug-17 & 187,000 & 153,000 & 448,000 & 294,000 \\
\hline Jul-17 & 186,000 & 150,000 & 441,000 & 291,000 \\
\hline Aug-16 & 192,000 & 136,000 & 446,000 & 260,000 \\
\hline $\begin{array}{l}\text { Month- } \\
\text { over- } \\
\text { month } \\
\text { change }\end{array}$ & $0.5 \%$ & $2.0 \%$ & $1.6 \%$ & $1.0 \%$ \\
\hline $\begin{array}{l}\text { Year- } \\
\text { over- } \\
\text { year } \\
\text { change }\end{array}$ & $-2.6 \%$ & $12.5 \%$ & $0.4 \%$ & $13.1 \%$ \\
\hline
\end{tabular}

\section{Housing Completions}

Total completions in August 2017 were at a SAAR of $1,075,000$. This is $10.2 \%$ less than July 2017 and $3.4 \%$ more than August 2016. SF completions were 724,000, which is 13.3\% less than July 2017. MF completions of two to four units were 3,000 and five units or more were 348,000 (Census Bureau 2017a).

The South remains the strongest market, where total completions were 491,000, of which 366,000 were SF and 125,000 were MF. The West followed with total completions of 270,000 units, of which 177,000 were SF and 93,000 were MF. Midwest total completions were 173,000 , of which 121,000 were SF and 52,000 were MF. Total Northeast completions were 141,000, of which 60,000 were SF and 81,000 were MF (Census Bureau 2017a). Table 4 provides specific information on each completion category for August 2017.

Table 4-National and regional U.S. housing completions for August 2017 in comparison to July 2017 and August 2016

\begin{tabular}{|c|c|c|c|c|}
\hline & $\begin{array}{c}\text { Total } \\
\text { completions }^{\mathrm{a}}\end{array}$ & $\begin{array}{l}\text { Single- } \\
\text { family }\end{array}$ & 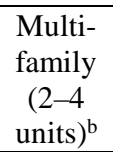 & $\begin{array}{l}\text { Multi- } \\
\text { family } \\
\text { ( } \geq 5 \\
\text { units) }\end{array}$ \\
\hline Aug-17 & $1,075,000$ & 724,000 & 3,000 & 348,000 \\
\hline Jul-17 & $1,197,000$ & 835,000 & 7,000 & 355,000 \\
\hline Aug-16 & $1,040,000$ & 744,000 & 8,000 & 288,000 \\
\hline $\begin{array}{l}\text { Month- } \\
\text { over- } \\
\text { month } \\
\text { change }\end{array}$ & $-10.2 \%$ & $-13.3 \%$ & $-57.1 \%$ & $-2.0 \%$ \\
\hline $\begin{array}{l}\text { Year- } \\
\text { over- } \\
\text { year } \\
\text { change }\end{array}$ & $3.4 \%$ & $-2.7 \%$ & $-62.5 \%$ & $20.8 \%$ \\
\hline
\end{tabular}

\begin{tabular}{lcccc} 
& Northeast & Midwest & South & West \\
\cline { 2 - 5 } Aug-17 & 141,000 & 173,000 & 491,000 & 270,000 \\
Jul-17 & 109,000 & 175,000 & 631,000 & 282,000 \\
Aug-16 & 130,000 & 150,000 & 541,000 & 219,000 \\
Month- & $29.4 \%$ & $-1.1 \%$ & $-22.2 \%$ & $-4.3 \%$ \\
over- & & & \\
month \\
change
\end{tabular}




\section{New Single-Family House Sales}

Total new house sales in August 2017 were estimated at a SAAR of 560,000 units. This was a decrease of $3.4 \%$ from July 2017 and 1.2\% less than August 2016. Regionally, the South remains the strongest market, with total new SF house sales of 307,000 , followed by the West with 146,000 . The Midwest had 69,000 sales, and the Northeast had 38,000 (Census Bureau 2017b).

The median sales price of new houses sold in August 2017 was $\$ 300,200$, and the mean sales price was $\$ 368,100$ (Census Bureau 2017b). Table 5 provides specific information on each house sales category for August 2017.

Table 5-National U.S. housing sales data for August 2017 in comparison to July 2017 and August 2016

\begin{tabular}{|c|c|c|c|c|}
\hline & $\begin{array}{l}\text { New } \\
\text { single- } \\
\text { family } \\
\text { sales }^{\mathrm{a}}\end{array}$ & $\begin{array}{c}\text { Median } \\
\text { price }\end{array}$ & $\begin{array}{l}\text { Mean } \\
\text { price }\end{array}$ & $\begin{array}{l}\text { Month's } \\
\text { supply }\end{array}$ \\
\hline Aug-17 & 560,000 & $\$ 300,200$ & $\$ 368,100$ & 6.1 \\
\hline Jul-17 & 580,000 & $\$ 319,900$ & $\$ 371,300$ & 5.7 \\
\hline Aug-16 & 567,000 & $\$ 298,900$ & $\$ 355,100$ & 5.1 \\
\hline $\begin{array}{l}\text { Month- } \\
\text { over- } \\
\text { month } \\
\text { change }\end{array}$ & $-3.4 \%$ & $-6.2 \%$ & $-0.9 \%$ & $7.0 \%$ \\
\hline \multirow{2}{*}{$\begin{array}{l}\text { Year- } \\
\text { over- } \\
\text { year } \\
\text { change }\end{array}$} & $-1.2 \%$ & $0.4 \%$ & $3.7 \%$ & $19.6 \%$ \\
\hline & Northeast & Midwest & South & West \\
\hline Jul-17 & 38,000 & 69,000 & 307,000 & 146,000 \\
\hline Jun-17 & 39,000 & 69,000 & 322,000 & 150,000 \\
\hline Jul-16 & 23,000 & 66,000 & 338,000 & 140,000 \\
\hline $\begin{array}{l}\text { Month- } \\
\text { over- } \\
\text { month } \\
\text { change }\end{array}$ & $-2.6 \%$ & $0.0 \%$ & $-4.7 \%$ & $-2.7 \%$ \\
\hline $\begin{array}{l}\text { Year- } \\
\text { over- } \\
\text { year } \\
\text { change }\end{array}$ & $65.2 \%$ & $4.5 \%$ & $-9.2 \%$ & $4.3 \%$ \\
\hline
\end{tabular}

\section{Private Residential Construction Spending}

New SF starts and sales are vital to the wood products industry, as new units consume more value-added products than any other wood consuming sector. Aggregate new housing construction spending has generally lagged the overall economy since 2010. New construction and spending are two of the factors often mentioned for the subdued economic recovery and the expenditure data bear this out. Total private residential construction spending for August 2017 was \$520,912 million, an increase of 0.4\% from July 2017 and an 11.6\% increase over August 2016. SF construction spending in August 2017 was \$263,732 million and MF construction spending was $\$ 62,343$. Improvement or remodeling spending was $\$ 194,837$ million (Census Bureau 2017c). Table 6 provides specific information on each construction spending category for August 2017.

Table 6-National U.S. housing construction spending for August 2017 in comparison to July 2017 and August 2016

\begin{tabular}{lcccc}
\hline & $\begin{array}{c}\text { Total private } \\
\text { residential } \\
\text { construction } \\
\text { spending, b }\end{array}$ & $\begin{array}{c}\text { Single- } \\
\text { family }\end{array}$ & $\begin{array}{c}\text { Multi- } \\
\text { family }\end{array}$ & $\begin{array}{c}\text { Improve- } \\
\text { ment }^{\mathrm{c}}\end{array}$ \\
\hline Aug-17 & $\$ 520,912$ & $\$ 263,732$ & $\$ 62,343$ & $\$ 194,837$ \\
Jul-17 & $\$ 518,591$ & $\$ 262,951$ & $\$ 61,784$ & $\$ 193,856$ \\
Aug-16 & $\$ 466,559$ & $\$ 237,288$ & $\$ 60,965$ & $\$ 168,306$ \\
Month- & $0.4 \%$ & $0.3 \%$ & $0.9 \%$ & $0.5 \%$ \\
over- & & & \\
month & & & \\
change & & & \\
Year- \\
over-
\end{tabular}




\section{Existing House Sales}

Existing house sales in August 2017 were at a SAAR of 5,350,000 units. This is a 1.7\% decrease from July 2017 and a $0.2 \%$ decline from August 2016. Regionally, the South remains the strongest market, with total existing house sales of 2,150,000 units, followed by the Midwest at 1,280,000 units. The West had total existing sales of 1,200,000 units, and the Northeast had 720,000 units. Table 7 provides specific information on each existing house sales category for August 2017.

Table 7-National U.S. existing house sales for August 2017 in comparison to July 2017 and August 2016

\begin{tabular}{|c|c|c|c|c|}
\hline & $\begin{array}{c}\text { Existing } \\
\text { house } \\
\text { sales }^{\mathrm{a}}\end{array}$ & $\begin{array}{l}\text { Median } \\
\text { price }\end{array}$ & Mean price & $\begin{array}{c}\text { Month’s } \\
\text { supply }\end{array}$ \\
\hline Aug-17 & $5,350,000$ & $\$ 253,500$ & $\$ 294,600$ & 4.2 \\
\hline Jul-17 & $5,440,000$ & $\$ 258,100$ & $\$ 298,800$ & 4.2 \\
\hline Aug-16 & $5,340,000$ & $\$ 240,000$ & $\$ 282,000$ & 4.5 \\
\hline $\begin{array}{l}\text { Month- } \\
\text { over- } \\
\text { month } \\
\text { change }\end{array}$ & $-1.7 \%$ & $-1.8 \%$ & $-1.4 \%$ & $0.0 \%$ \\
\hline $\begin{array}{l}\text { Year- } \\
\text { over- } \\
\text { year } \\
\text { change }\end{array}$ & $0.2 \%$ & $5.6 \%$ & $4.5 \%$ & $-6.7 \%$ \\
\hline Aug-17 & $\begin{array}{c}\text { Northeast } \\
720,000\end{array}$ & $\begin{array}{c}\text { Midwest } \\
1,280,000\end{array}$ & $\begin{array}{c}\text { South } \\
2,150,000\end{array}$ & $\begin{array}{c}\text { West } \\
1,200,000\end{array}$ \\
\hline Jul-17 & 650,000 & $1,250,000$ & $2,280,000$ & $1,260,000$ \\
\hline Aug-16 & 710,000 & $1,270,000$ & $2,170,000$ & $1,190,000$ \\
\hline $\begin{array}{l}\text { Month- } \\
\text { over- } \\
\text { month } \\
\text { change }\end{array}$ & $10.8 \%$ & $2.4 \%$ & $-5.7 \%$ & $-4.8 \%$ \\
\hline $\begin{array}{l}\text { Year- } \\
\text { over- } \\
\text { year } \\
\text { change }\end{array}$ & $1.4 \%$ & $0.8 \%$ & $-0.9 \%$ & $0.8 \%$ \\
\hline
\end{tabular}

\section{Literature Cited}

Census Bureau. 2017a. New residential construction. Washington, DC: U.S. Department of Commerce, Census Bureau. Available at www.census.gov/construction/c30/c30index.html. (Accessed September 19, 2017).

Census Bureau. 2017b. New residential sales. Washington, DC: U.S. Department of Commerce, Census Bureau.

Available at

www.census.gov/construction/c30/historical_data.html. (Accessed September 26, 2017).

Census Bureau. 2017c. Value of construction put in place at a glance. Washington, DC: U.S. Department of Commerce, Census Bureau. Available at

www.census.gov/construction/nrc/. (Accessed October 2, 2017).

National Association of Realtors. 2017. Existing home sales. Available at www.nar.realtor/topics/existing-homesales. (Accessed September 20, 2017). 


\section{Glossary}

Housing completions-A house is defined as completed when all finished flooring has been installed (or carpeting if used in place of finished flooring). If the building is occupied before all construction is finished, it is classified as completed at the time of occupancy. In privately-owned buildings with two or more housing units, all of the units in the buildings are counted as completed when 50 percent or more of the units are occupied or available for occupancy. Housing completions are estimated for all areas of the United States, regardless of whether permits are required.

Housing permits-The approval given by a local jurisdiction to proceed on a construction project. Note that not all areas of the country require a permit for construction.

Housing starts-Start of construction occurs when excavation begins for the footings or foundation of a building. All housing units in a multifamily building are defined as being started when this excavation begins. Beginning with data for September 1992, estimates of housing starts include units in structures being totally rebuilt on an existing foundation.

Housing under construction-Estimates of housing units started, but not yet completed, are estimated for all areas of the United States, regardless of whether permits are required.

Regions-Northeast: Connecticut, Maine, Massachusetts, New Hampshire, New Jersey, New York, Pennsylvania, Rhode Island, and Vermont. Midwest: Illinois, Indiana, Iowa, Kansas, Michigan, Minnesota, Missouri, Nebraska, North Dakota, Ohio, South Dakota, and Wisconsin. South: Alabama, Arkansas, Delaware, District of Columbia, Florida, Georgia, Kentucky, Louisiana, Maryland, Mississippi, North Carolina, Oklahoma, South Carolina, Tennessee, Texas, Virginia, and West Virginia. West: Alaska, Arizona, California, Colorado, Hawaii, Idaho, Montana, Nevada, New Mexico, Oregon, Utah, Washington, and Wyoming.

Seasonally adjusted annual rate-Seasonal adjustment is the process of estimating and removing seasonal effects from a time series to better reveal certain non-seasonal features such as underlying trends and business cycles. Seasonal adjustment procedures estimate effects that occur in the same calendar month with similar magnitude and direction from year to year. In series whose seasonal effects come primarily from weather, the seasonal factors are estimates of average weather effects for each month.

Single-family housing —Dwellings that include fully detached, semidetached (semi-attached, side-by-side), row houses, and townhouses. 